\title{
Hypobaric Storage of Representative Root, Leaf, Fruit, and Flower Tissues: Comparisons to Storage at Atmospheric Pressure and Normoxia
}

\author{
Benjamin Paskus \\ Department of Horticulture, Michigan State University, East Lansing, MI \\ 28824
}

Patrick Abeli

Department of Horticulture and Natural Resources, K-State Olathe, 22201 W. Innovation Drive, Olathe, KS 66061

\section{Randolph Beaudry \\ Department of Horticulture, Michigan State University, East Lansing, MI 28824}

Additional index words. humidity, corolla, flower, hypobaric, desiccation, rose

\begin{abstract}
Hypobaric or low-pressure storage (LPS) is a technology that has been reported to have significant potential to preserve fresh produce quality. However, excessive moisture loss has often been erroneously reported to limit the utility of LPS. We report on hypobaric (1.6 to $2.0 \mathrm{kPa})$ storage of representative bulky and leafy fruits and vegetables sstrawberry (Fragaria Xananassa Duchesne ex Rozier) fruit, carrot [Daucus carota subsp. sativus (Hoffm.) Arcang.] roots, spinach (Spinacia oleracea L.) leaves, and rose (Rosa $\times$ hybrida 'Attaché Pink') flowers $\}$ using a laboratory-scale LPS and provide data on the regulation of humidity and temperature and describe effects on moisture loss and quality. The LPS achieved near saturation $(>99.5 \%)$ of water without condensation on the chamber sidewalls. This required tight regulation of the chamber wall temperature $\left(2.2^{\circ} \mathrm{C} \pm 0.15^{\circ} \mathrm{C}\right)$ and careful control of the flux of air into the chamber. The rate of moisture loss was unaffected by the pressure of the storage atmosphere; however, it was affected by commodity, being lower for strawberry than for carrot or spinach, and averaging $0.08 \%, 0.40 \%$, and $0.35 \%$ per day, respectively (average of normal and low pressure combined). Moisture loss of longstemmed rose in LPS averaged $0.071 \%$ per day over an 8-week storage period. Although moisture loss was low, the LPS environment appeared to enhance water loss from deeper within plant tissues than storage at atmospheric pressure and, in roses, resulted in bent neck 2 or 3 days after removal from storage after 3 weeks. For this reason, LPS did not benefit storability of cut 'Attaché Pink' roses compared with high-humidity chambers maintained at atmospheric pressure.
\end{abstract}

The primary functions of hypoxia (low oxygen) in the storage of perishables are to inhibit ethylene action, to reduce metabolic rate through respiratory inhibition, and to reduce cut surface browning (Beaudry, 1999, 2000; Burg and Burg, 1965). Nitrogen flushing is typically used to achieve the low $\mathrm{O}_{2}$ atmosphere of controlled atmosphere (CA) storage.

Received for publication 25 Feb. 2021. Accepted for publication 8 Apr. 2021.

Published online 2 June 2021.

We thank American Food Technologies SCIP/ TCA, for their support of this study. R.B. acknowledges support from Michigan AgBioResearch and the USDA National Institute of Food and Agriculture, Hatch project MICL002688.

R.B. is the corresponding author. E-mail: beaudry@ msu.edu.

This is an open access article distributed under the CC BY-NC-ND license (https://creativecommons. org/licenses/by-nc-nd/4.0/).
The $\mathrm{O}_{2}$ partial pressure in LPS is a function of the absolute pressure, humidity, the inlet air flow rate, and the rate of $\mathrm{O}_{2}$ consumption by the commodity. The LPS environment is unique in that, when the structure is properly designed and managed, water vapor is one of the major constituents in the atmosphere (Dilley et al., 1975). For example, at $1.5 \mathrm{kPa}(11.3 \mathrm{~mm} \mathrm{Hg})$ and $0{ }^{\circ} \mathrm{C}$, if the atmosphere is kept close to saturation, the water vapor partial pressure will be near $0.6 \mathrm{kPa}$ $(8.15 \mathrm{~mm} \mathrm{Hg}$ ) or $\approx 40 \%$ of the total pressure. In this case, the $\mathrm{O}_{2}$ partial pressure would be approximately one-fifth of the remaining pressure, or $0.18 \mathrm{kPa}$, and the corresponding $\mathrm{N}_{2}$ partial pressure would be $0.72 \mathrm{kPa}$. Thus, in LPS, water vapor comprises a much higher total proportion of the atmosphere than at normal ambient pressure, where, at saturation, the water vapor makes up only $0.6 \%$ of the atmosphere $(0.6 \mathrm{kPa})$ at $0{ }^{\circ} \mathrm{C}$. The extremely high proportion of water vapor in the LPS environment means that those factors that alter the humidity of the low-pressure (LP) chamber will markedly alter the concentration of $\mathrm{O}_{2}$. This, in turn, emphasizes the importance of regulating the humidity in an LPS room.

LPS has not been widely used in the United States. In fact, the authors are aware of its commercial use as a permanent installation in only one facility (JA Flower Services, Miami, FL) for the temporary storage of imported floral crops. Dormavac, the Grumman subsidiary company that attempted to commercialize LPS in the 1970s and 1980s was ended in 1982 (The New York Times, 1982). Currently more widespread use is apparently found in China (Zheng, 2018) and in the United States, marketed as RipeLocker (Koger, 2021).

One of the criticisms of LPS is the potential for excessive water loss (Burg, 2004; Hughes et al., 1981; Ilangantileke et al., 1989; Lougheed et al., 1977, 1978). However, Burg (2004) effectively argues that through either moist or "dry" humidification systems, moisture loss can be minimized such that the LPS can "maintain the highest possible humidity." Humidification of the incoming air is best achieved after the transition to LP. By humidifying the incoming air at LP, rather than before, desiccation of the incoming air due to expansion can be avoided and a near saturated atmosphere maintained. Further, the water added to the incoming atmosphere is sometimes heated to offset the cooling due to evaporation and enhance the water content in the inlet air. In the dry humidification system, water loss that accompanies dissipation of the heat from respiration is leveraged for the humidification of the chamber atmosphere.

Data demonstrating the humidity in properly managed LPS environments are not commonly found in the published literature, in fact, in the peer-reviewed literature, we found humidity measurements in only one study and in that study, produce was not included within the chamber (Jiao et al., 2012). Jiao et al. (2012) reported humidity levels greater than $99 \%$ for a commercially built laboratory-scale LPS intended for use as a tool for 


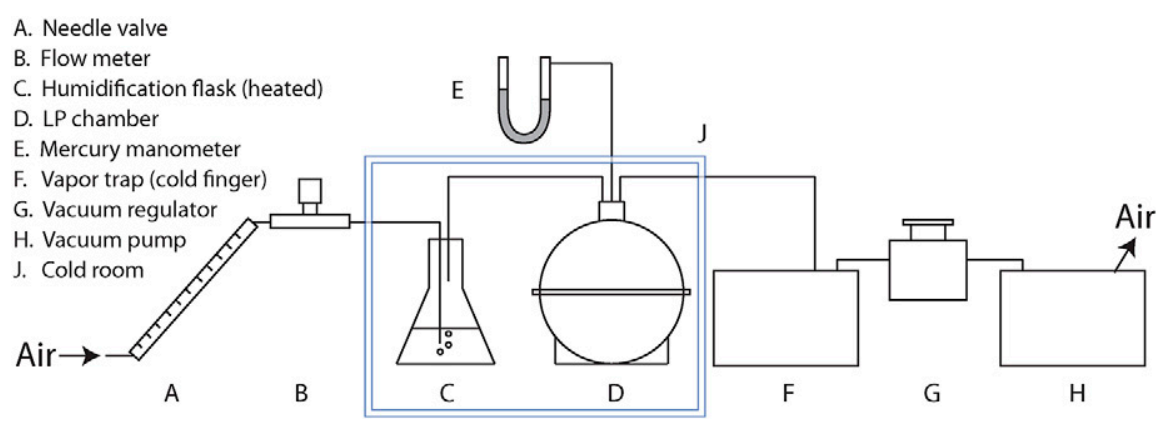

Fig. 1. Schematic design of the research-scale hypobaric system constructed according to Burg (2004).

disinfestation of fruits. We were also unable to find accurate measures of temperature for perishables, objects, chamber, and air in LPS systems to determine if insulation due to the Dewar effect was problematic for heat retention
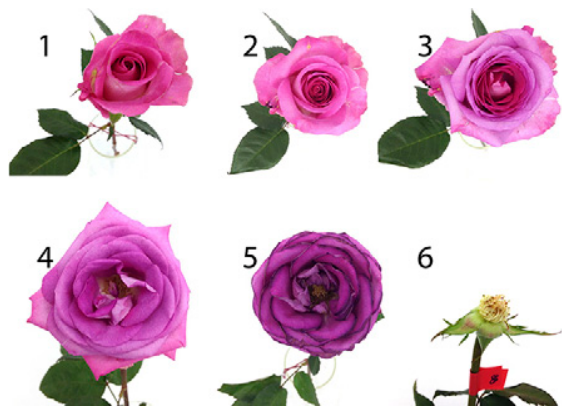

6

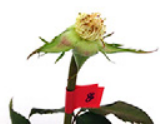

Fig. 2. Rose development index used in this study and based on that used by Capdeville et al. (2005). Stage 3 was taken to be the limit of salability.

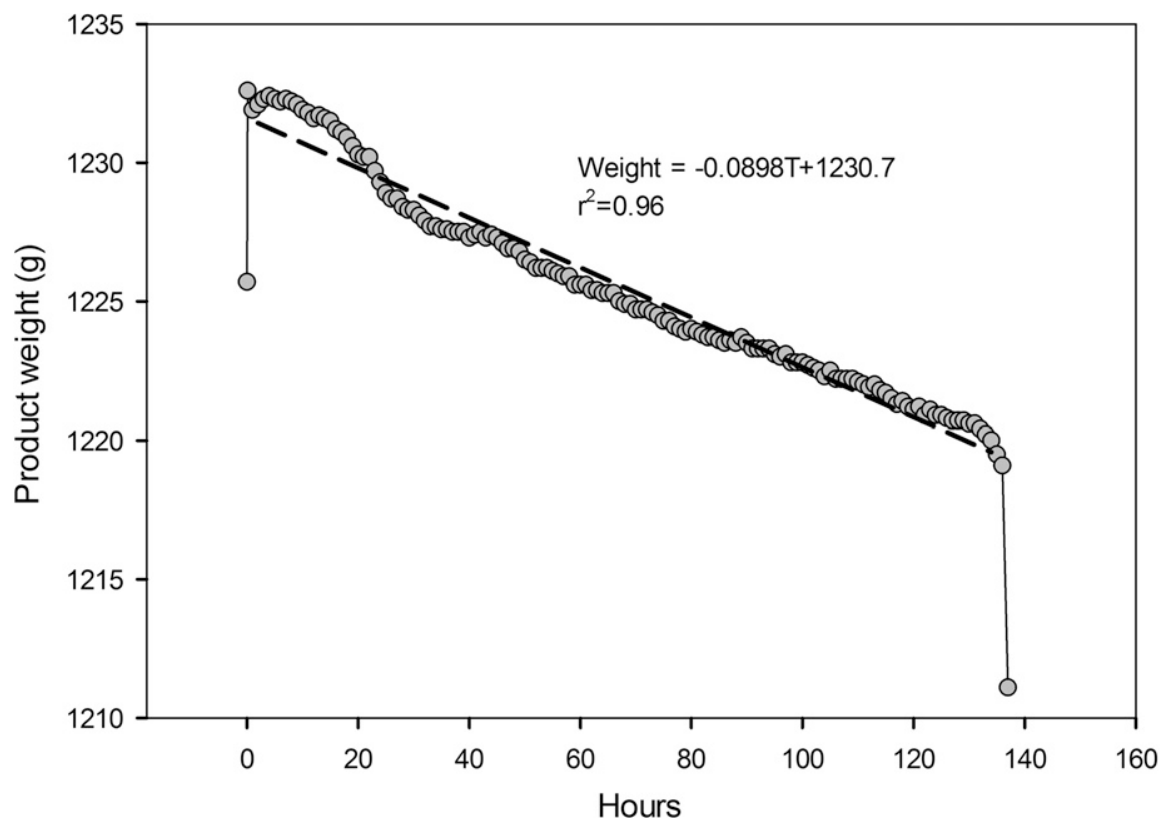

Fig. 3. Representative curve for the change in weight of a combined load of spinach $(\approx 275 \mathrm{~g})$, strawberry fruit $(\approx 520 \mathrm{~g})$, and carrots $(\approx 400 \mathrm{~g})$ over a 5.5 -day storage period in a 180 -L low-pressure chamber at $2{ }^{\circ} \mathrm{C}$. The initial increase in weight is due to the loss of buoyancy of the air on pulling the vacuum to $1.6 \mathrm{kPa}(12 \mathrm{~mm} \mathrm{Hg})$ and the rapid decline in weight at the end of the experiment is due to the increase in buoyancy of the atmosphere on restoration of atmospheric pressure. The slope of the fitted line between hour 2 and hour 134 is $-0.0898 \mathrm{~g} \cdot \mathrm{h}^{-1}$, equivalent to a moisture loss rate of $0.18 \%$ per day for the combined load.

\section{Materials and Methods}

Design of the LPS system. A laboratory LPS system was built according to Burg (2004) consisting of a vacuum pump, a vacuum regulator, a water vapor trap, a refrigerated storage chamber, a humidifier, a needle valve, a flow meter, and air supply, with each piece connected using wire-reinforced vacuum tubing with NPT hose barb connections secured with hose clamps (Fig. 1). Four specially built airtight 180-L aluminum chambers were constructed for commodity storage.

Chambers were constructed from a 0.9 $\mathrm{cm}$-thick aluminum sheet rolled into a cylinder $0.6 \mathrm{~m}$ in diameter and $0.6 \mathrm{~m}$ in height. The cylinder was welded at the seam and an aluminum base plate (1.4-cm-thick) was attached by welding. A circular rubber gasket with a U-shaped profile was fitted to the upper lip of the cylinder. During operation, a light layer of silicone vacuum grease was applied to the top of the cylinder and to the contact point between the gasket and the lid. The lid was a 1.4-cm-thick sheet of aluminum fitted with handles. The cylinder wall was fitted with three 1.9-cm-ID NPT-threaded female couplings. One was attached to the inlet air line, a second was attached to the vacuum (outlet) line, and the third was used to admit sensor wires. Wire penetrations were accomplished using hermetic bulkhead connectors (model PT8-SS-200-9-TZ22-24-24; Pave Technology Co., Dayton, OH). The LPS cylinder was tested for leakage and found to maintain $<0.5 \mathrm{~mm} \mathrm{Hg}$ with no apparent increase in pressure in an overnight test. The lack of a measurable leak in the system was expected to maximize performance in terms of humidity management (Jiao et al., 2012).

Vacuum was maintained with a rotaryvane vacuum pump (model W2V20; LACO Technologies, Salt Lake City, UT) fitted with an inlet filter and an oil condenser on the exhaust port. Vacuum was controlled using a vacuum regulator (Model 329SR-500; L.J. Engineering Inc., Huntington Beach, CA). To prevent moisture from the produce in the chamber from reaching the vacuum pump, a cryo-based vapor trap (model RVT400; Thermo Electron, Waltham, MA) was placed between the chamber and the pressure regulator and maintained at $-50^{\circ} \mathrm{C}$ and $100 \mathrm{~Pa}$ to capture the water vapor as a solid phase. The gas ballast was typically closed on the vacuum pump when the vapor trap was used.

The flow rate through the LP and NP chambers was regulated using a stainless steel fine metering valve (S-series; Swagelok, Solon, $\mathrm{OH}$ ) and measured using a $20-\mathrm{mL}$ glass bubble meter. The inlet air for the LP chamber was humidified at low pressure by running the air supply through a 1-L Pyrex heavy-duty side-arm Erlenmeyer flask containing $250 \mathrm{~mL}$ deionized water. The humidification flask was housed in the cold room outside the LP chamber and warmed to 3 to $10^{\circ} \mathrm{C}$. An aerator stone was attached to the submerged end of the inlet line to humidify inlet air. All vacuum lines were wire helix reinforced PVC (Grainger Approved PVC 
Tubing; Grainger, Lake Forest, IL). The inlet air into the 180-L chambers operated at NP was not humidified. In this case, the drop in temperature of the incoming ventilation air passively controlled humidity. The inlet air was $30 \%$ to $40 \%$ relative humidity $(\mathrm{RH})$ at $20^{\circ} \mathrm{C}$, providing 0.69 to $0.92 \mathrm{kPa} \mathrm{H}_{2} \mathrm{O}$ vapor, respectively. At $2{ }^{\circ} \mathrm{C}$, saturated air possesses $0.72 \mathrm{kPa} \mathrm{H}_{2} \mathrm{O}$ vapor, so the incoming chamber air should have been near saturation on cooling. During the experiment, condensation was evident within the NP chamber, suggesting the atmosphere was near saturation.

The 180-L chambers were not themselves refrigerated, but rather, temperature regulation was accomplished by placing the chambers in a controlled temperature room maintained at $2{ }^{\circ} \mathrm{C}$. Temperatures of the chamber walls, the plastic crate housing the produce, and the product were monitored using copper-constantan thermocouples. The temperature of the air (dry bulb and the wet bulb temperature) was monitored by high accuracy RTD probes (P-M-1/ 10-1/8-2-0-T-6; Omega Engineering, Stamford, CT). The data were logged using a highresolution data logger (PT104A; Omega Engineering) to enable measurements of $\pm 0.01{ }^{\circ} \mathrm{C}$ for calculation of RH levels greater than $99 \%$. The wet bulb temperature was measured using

the RTD probe inserted in a cotton wet bulb "sock" with the opposite end of the sock immersed in a distilled water reservoir in a suspended $15-\mathrm{mL}$ plastic centrifuge tube and held $5 \mathrm{~cm}$ away from the chamber side wall. $\mathrm{RH}$ was calculated from the water vapor saturation pressure (Wagner and Pruß, 2002) using pressure correction according to Vaisala (2013).

Plant material evaluation. Temperature, moisture loss, and quality retention were evaluated for bunch carrot (Daucus carota) with intact crown and leaves, bunch spinach (Spinacia oleracea), strawberry (Fragaria $\times$ ananassa Duchesne ex Rozier), and longstemmed rose (Rosa ×hybrida 'Attaché Pink') flowers. The carrot, spinach, strawberry, and rose were selected as highly perishable root, leaf, fruit, and floral crops. Carrots, spinach, and strawberry fruit were purchased from a local retailer. Roses were sourced from Nordlie Inc. in Grand Rapids, MI, on the day of their arrival in the United States and 2 to $3 \mathrm{~d}$ following harvest in Colombia.

Weight loss was tracked for roses, but additional quality data collected included incidence of decay, stage of development, and the angle of the bloom relative to the axis of the stem. The stage of development was determined using an index (1-6) developed for

Table 1. Analysis of variance for the impact of pressure (101.3 and $1.6 \mathrm{kPa}$ ) and plant species (strawberry fruit, carrot root with intact tops, and bundled spinach leaves) on moisture loss following $5.5 \mathrm{~d}$ of storage in ventilated $180-\mathrm{L}$ aluminum chambers held at $2.2^{\circ} \mathrm{C}$.

\begin{tabular}{lrlrrr}
\hline Source of variation & df & \multicolumn{1}{c}{ SS } & \multicolumn{1}{c}{ MS } & F & $P$ \\
\hline Pressure & 1 & 0.0000117 & 0.0000117 & 0.492 & 0.496 \\
Species & 2 & 0.00107 & 0.000533 & 22.481 & $<0.001$ \\
Pressure $\times$ Species & 2 & 0.0000431 & 0.0000216 & 0.909 & 0.429 \\
Residual & 12 & 0.000285 & 0.0000237 & & \\
Total & 17 & 0.00141 & 0.0000827 & & \\
\hline
\end{tabular}

$\mathrm{SS}=$ sum of squares value; MS = mean square value.

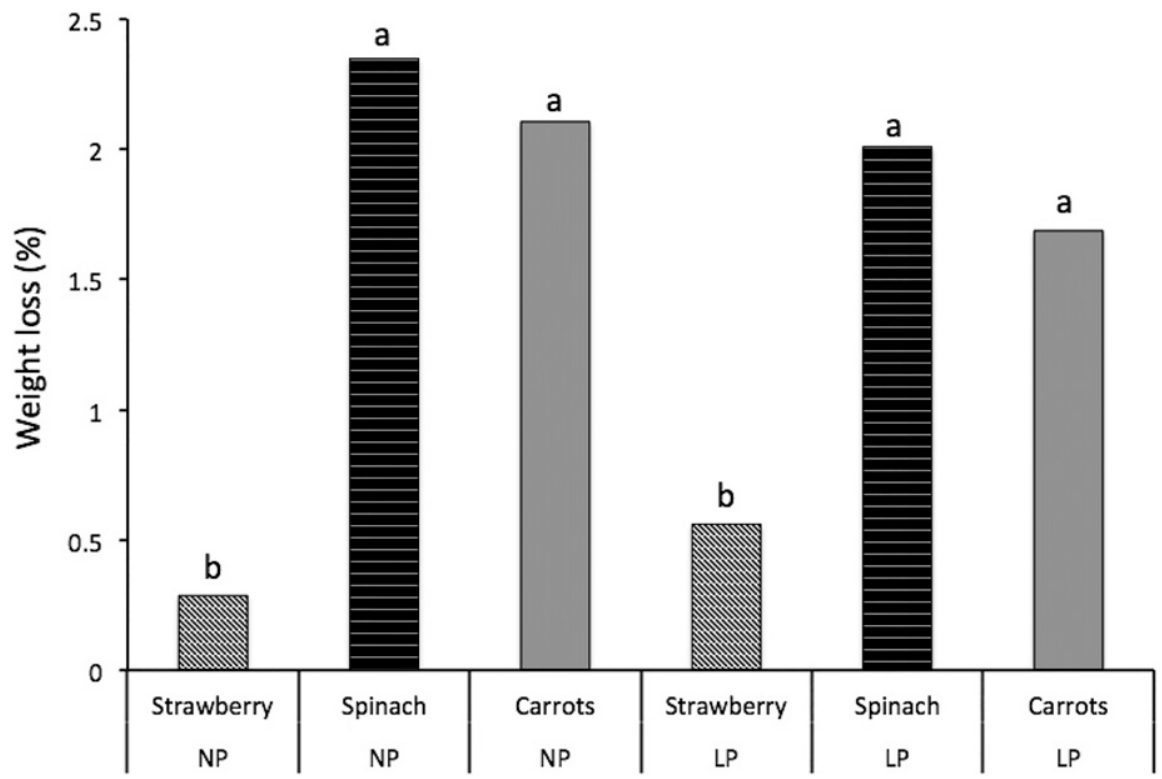

Fig. 4. Change in weight of spinach $(\approx 275 \mathrm{~g})$, strawberry fruit $(\approx 520 \mathrm{~g})$, and carrots $(\approx 400 \mathrm{~g})$ over a 5.5 -day storage period in normal pressure $(\mathrm{NP}, 101 \mathrm{kPa})$ or low pressure $(\mathrm{LP}, 1.6 \mathrm{kPa})$ in $180-\mathrm{L}$ sealed aluminum chambers at $2{ }^{\circ} \mathrm{C}$. Significant differences between means $(P<0.001$, pairwise multiple comparison procedures, Holm-Sidak method) are denoted by different letters above the treatment histograms. this study (Fig. 2), which is based on that used by Capdeville et al. (2005). Stems were trimmed to $40-\mathrm{cm}$ in length before applying storage treatments and left in their plastic shipping sleeves during storage.

Expt. 1: Weight loss study with leafy and bulky commodities. The weight loss of botanically diverse perishables, carrot roots with tops attached, spinach leaves, and strawberry fruit, was monitored in 180-L storage chambers to better understand the dynamics of water vapor movement for bulky and leafy products. The flow rates of $11.8 \mathrm{~mL} \cdot \mathrm{min}^{-1}$ for LP and $500 \mathrm{~mL} \cdot \mathrm{min}^{-1}$ for NP were selected so that ventilation rate, as a fraction of chamber volume, was relatively similar for NP and LP chambers (approximately onefourth to one-sixth of a volume change per hour). The storage duration was $5.5 \mathrm{~d}$ and the target temperature was $2^{\circ} \mathrm{C}$. Each chamber had one bunch of spinach $(\approx 275 \mathrm{~g})$, one package of strawberry fruit $(\approx 520 \mathrm{~g})$, and one bunch of carrots $(\approx 400 \mathrm{~g})$ contained in a 500 -g high-density polyethylene plastic crate. The total product mass of perishables in the chambers was $\approx 1.2 \mathrm{~kg}$. The study was replicated three times. For each of the three experimental runs, one lot of each commodity was stored at a low pressure of $1.6 \pm 0.015 \mathrm{kPa}$ (LP, $12 \mathrm{~mm} \mathrm{Hg}, 0.18 \mathrm{kPa} \mathrm{O}_{2}$ ) and one lot was maintained at normal pressure at 101.3 $\mathrm{kPa}\left(\mathrm{NP}, 760 \mathrm{~mm} \mathrm{Hg}, 20.9 \mathrm{kPa} \mathrm{O}_{2}\right.$ ). The previously described 180 -L aluminum chambers were used for both NP and LP storage.

Three additional lots of produce were held for 3 weeks at $2{ }^{\circ} \mathrm{C}$ at NP and LP to determine water loss over a longer period and to perform quality analysis for spinach. The amount of desiccated and yellowed spinach was determined following a single run for 3 weeks of storage at NP (1 chamber) and LP ( 3 chambers) at $2^{\circ} \mathrm{C}$ by weighing the affected and unaffected tissue. Quality evaluations for carrot and strawberry were not performed.

The air ventilation rate through the LP chamber was $11.8 \mathrm{~mL} \cdot \mathrm{min}^{-1}$ at atmospheric pressure and $20^{\circ} \mathrm{C}$. This flow rate delivered $\mathrm{O}_{2}$ at a rate of $0.098 \mathrm{mmol} \cdot \mathrm{min}^{-1}$, which was estimated to be $\approx 10$-fold higher than the $\mathrm{O}_{2}$ use rate by respiration and estimated to be $0.011 \mathrm{mmol} \cdot \mathrm{min}^{-1}$ (Hardenburg et al., 1986). Under hypobaric conditions of $1.6 \mathrm{kPa}$, the chamber ventilation rate, on expansion of the incoming, humidified air, was $750 \mathrm{~mL} \cdot \mathrm{min}^{-1}$ (approximately one-fourth volume change per hour). The produce in the NP chamber was vented at a rate of $500 \mathrm{~mL} \cdot \mathrm{min}^{-1}$. To determine linearity of moisture loss under hypobaric conditions, in one LP chamber, produce weight was measured in real time using a platform scale within the chamber (model GBK16A; Adam Equip. Co., Oxford, CT) and proprietary software (AdamDU Data Collection Program, Adam Equip. Co.).

An analysis of variance was performed on temperatures of objects in the chamber (dry bulb, wet bulb, crate, chamber wall, and perishable product) and on moisture loss by the products using completely randomized designs and means separation was by the HolmSidak method $(P<0.05)$ as determined using 

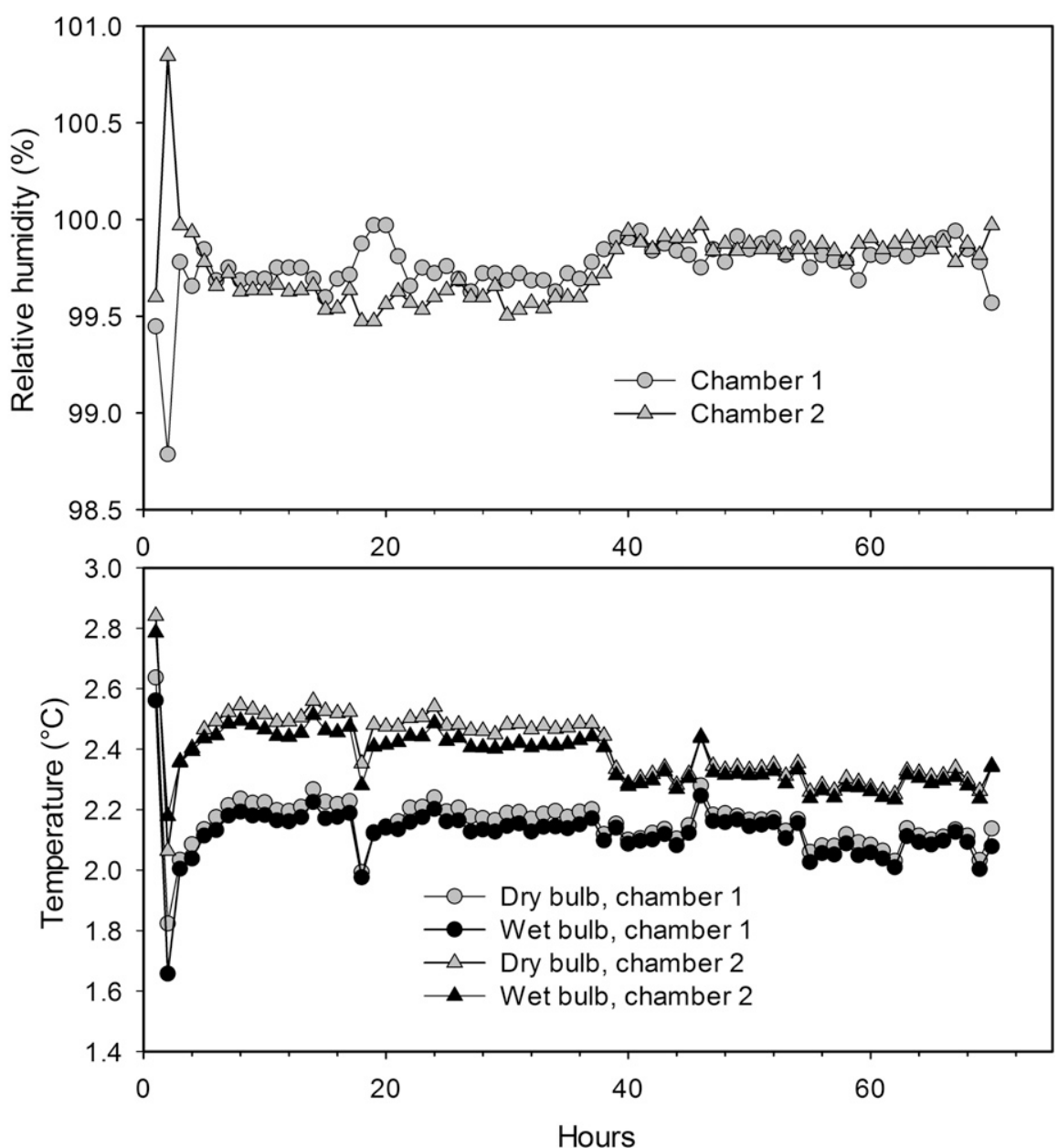

Fig. 5. Temperature of wet and dry bulb thermocouples and relative humidity in two replicate LPS chambers containing $\approx 1.2 \mathrm{~kg}$ of mixed produce (strawberry, fruit, carrots with tops intact, and bunched spinach) and operated at $1.6 \mathrm{kPa}$ in a controlled temperature room set to run at $2{ }^{\circ} \mathrm{C}$. Chamber 1 was nearer to the evaporator coil and cooling fan than chamber 2 , resulting in a slightly lower temperature for the former, but having little impact on humidity. Relative humidity calculations were based on recorded wet and dry bulb temperatures according to the method of Vaisala (2013).

a commercial software package (SigmaPlot 12.5; Systat Software, Inc., Chicago, IL).

Expt. 2: Rose weight loss and quality. For the rose flower study, an index (1-6) was developed based on the ontogeny of rose blossom expansion, color change, and abscission (Fig. 2). In addition, a neck quality index was developed to describe the degree of bending of the peduncle relative to the long axis of the stem $(1=$ no bending; $2=$ bending $\leq$ $15^{\circ} ; 3=$ bending $>15^{\circ}$ and $\leq 45^{\circ} ; 4=$ bending $>45^{\circ}$ and $\leq 90^{\circ} ; 5=$ bending $>90^{\circ}$ ). For the experimental runs, roses were divided into 19 lots, with each lot consisting of a single, bound, bunch containing 24 stems in a plastic sleeve. One lot was immediately moved to a room held at $20^{\circ} \mathrm{C}$. The other 18 lots were held in a cold room at $2{ }^{\circ} \mathrm{C}$ for the duration of the storage treatments. Six lots (weighing $\approx 5.1 \mathrm{~kg}$ in total) were stored in a 180-L aluminum chamber maintained at 1.97 $\mathrm{kPa}\left(15 \mathrm{~mm} \mathrm{Hg}, 0.26 \mathrm{kPa} \mathrm{O}_{2}\right)$ and a high $\mathrm{RH}$ (>99.5\%); six additional lots were stored in a 180 -L chamber at NP $(\approx 101.3 \mathrm{kPa})$ and an $\mathrm{RH}$ of $\approx 99 \%$, and the six remaining lots were held in the commercial cardboard box used to ship roses and held at ambient pressure and an $\mathrm{RH}$ of $\approx 70 \%$. The storage chambers were previously cleaned and disinfected with a commercial solution (DCD; Floralife, Walterboro, SC) applied according to manufacturer's directions. The flow rate through each of the 180-L LP chambers was $11.8 \mathrm{~mL} \cdot \mathrm{min}^{-1}$ at atmospheric pressure. Under hypobaric conditions of $1.97 \mathrm{kPa}$, this equated to a flow of $600 \mathrm{~mL} \cdot \mathrm{min}^{-1}$. The roses in the NP chamber were vented with nonhumidified air (30\% to $40 \% \mathrm{RH}$ at $20{ }^{\circ} \mathrm{C}$ ) at a rate of $100 \mathrm{~mL} \cdot \mathrm{min}^{-1}$. A lower flow rate was used for the NP treatment than for Expt. 1 to ensure the highest possible level of chamber humidity while permitting an appropriate level of control over temperature and the buildup of respiratory $\mathrm{CO}_{2}$. The roses in the commercial boxes were not vented, but were subject to the airflow in the cold rooms under continuous circulation.

One lot of roses was removed for quality analysis after $1,2,3,4,6$, and 8 weeks. On each date, the chambers were opened briefly $(\approx 15 \mathrm{~min})$; sleeves of roses were weighed in the cold room; flowers were replaced or retained for poststorage analysis; and the atmosphere was reestablished. Atmosphere reestablishment was slow, requiring $\approx 60 \mathrm{~min}$ to avoid injury and excessive moisture loss from the product.

After removal from storage, each rose stem was trimmed to a $30-\mathrm{cm}$ length; leaves were removed and guard petals, which were often slightly damaged in transit, were removed as well. Stems were briefly placed into a wetting solution (Quick Dip 100, Floralife) according to the manufacturer's instructions. For quality analysis, each lot was divided into two groups of 12 stems each, placed in 2-L jars containing $500 \mathrm{~mL}$ of deionized water, and held at $20^{\circ} \mathrm{C}$ for $7 \mathrm{~d}$, with quality evaluations taking place on days 0,1 , $2,3,5$, and 7 .

\section{Results and Discussion}

Expt. 1. Weight loss of the combined load of $\approx 1.2 \mathrm{~kg}$ of carrot roots with tops, spinach leaves, and strawberry fruit was found to be linear with time at a (combined product) rate of $\approx 0.18 \%$ per day in the LP system when measured continuously with the in-chamber scale (Fig. 3). This was in close agreement with the average rate of weight loss for the combined load based on initial and final weights $(0.15 \% \pm 0.023 \%$ per day). The rate of moisture loss was unaffected by the pressure of the storage atmosphere; however, it was affected by commodity (Table 1), being lower for strawberry than for carrot or spinach (Fig. 4), averaging $0.08 \%, 0.40 \%$, and $0.35 \%$ per day, respectively, across NP and LP treatments. These rates are similar to those found in studies on storage of these commodities in high-humidity environments at low temperature. The rate of weight loss

Table 2. Effect of time, replicate chamber, and object on the measured hourly temperature over 23 successive hours during a 5.5-day storage period under normal pressure or low pressure in 180-L sealed aluminum chambers containing spinach $(\approx 275 \mathrm{~g})$, strawberry fruit $(\approx 520 \mathrm{~g})$, and carrots $(\approx 400 \mathrm{~g})$ in a $500 \mathrm{~g}$ HDPE plastic crate. Chambers were held in a cold room set to maintain $2{ }^{\circ} \mathrm{C}$. The experiment was replicated three times.

\begin{tabular}{lc}
\hline Category & Mean \\
\hline Replicate & \\
1 & $2.199 \mathrm{~b}^{\mathrm{z}}$ \\
2 & $2.318 \mathrm{a}$ \\
3 & $2.119 \mathrm{c}$ \\
Object & \\
Dry bulb & $2.312 \mathrm{a}$ \\
Wet bulb & $2.280 \mathrm{~b}$ \\
Crate & $2.215 \mathrm{c}$ \\
Strawberry & $2.204 \mathrm{c}$ \\
Chamber wall & $2.202 \mathrm{c}$ \\
Carrot & $2.157 \mathrm{~d}$ \\
Spinach & $2.103 \mathrm{e}$ \\
ANOVA & $P$ value \\
Replicate & $<0.001$ \\
Object & $<0.001$ \\
Replicate $\times$ object & 0.019 \\
\hline
\end{tabular}

${ }^{\mathrm{z}}$ Means in a column followed by different letters are significantly different $(P \leq 0.05)$.

ANOVA $=$ analysis of variance. 
Table 3. Loss in quality of roses $(n=24$ stems per week) due to the incidence of brown petals and completely decayed flowers and due to moisture loss $(n=6$ sleeves of 24 stems per week) following storage at ambient pressure during the latter half of the storage period (weeks 4,6 , and 8 pooled) in a commercial shipping box at normal pressure $(\mathrm{NP}, 101.3 \mathrm{kPa})$ or a $180-\mathrm{L}$ chamber at low pressure $(\mathrm{LP}, 1.97 \mathrm{kPa})$ in a $180-\mathrm{L}$ chamber at normal pressure held at $2^{\circ} \mathrm{C}$.

\begin{tabular}{|c|c|c|c|c|}
\hline Pressure & Storage container & $\begin{array}{c}\text { Flowers with petals } \\
\text { exhibiting some browning } \\
\text { from decay }(\%)\end{array}$ & $\begin{array}{l}\text { Flowers with } \\
\text { completely decayed } \\
\text { corollas }(\%)\end{array}$ & $\begin{array}{c}\text { Moisture } \\
\text { loss } \\
\text { (\% per day) }\end{array}$ \\
\hline$\overline{\mathrm{NP}}$ & Shipping box (control) & $16.7 \mathrm{a}^{\mathrm{z}}$ & $7.33 \mathrm{a}$ & $0.210 \mathrm{a}$ \\
\hline NP & $180-\mathrm{L}$ chamber & $3.0 \mathrm{~b}$ & $2.67 \mathrm{a}$ & $0.123 \mathrm{ab}$ \\
\hline LP & 180-L chamber & $2.3 \mathrm{~b}$ & $0.00 \mathrm{a}$ & $0.071 \mathrm{~b}$ \\
\hline
\end{tabular}

${ }^{\mathrm{z}}$ Means in a column followed by different letters are significantly different $(P \leq 0.05)$. for strawberry was similar to that reported for packaged whole strawberry fruit $(\approx 0.09 \%$ per day) held at $1{ }^{\circ} \mathrm{C}$ (Nunes et al., 1998). Mudau et al. (2018) found about $0.18 \%$ weight loss per day for spinach in perforated low-density polyethylene packages held at $4{ }^{\circ} \mathrm{C}$. For carrots, a weight loss rate of $0.14 \%$ per day was recorded for roots stored in microperforated packages at $4{ }^{\circ} \mathrm{C}$ (Mastromatteo et al., 2012).

Based on wet and dry bulb measurements within the LP chambers, RH was held between $99.5 \%$ and $99.8 \%$ (Fig. 4). This humidity level slightly surpassed that of the VivaFresh system (Model RDC-0005; Atlas Technologies, Port Townsend, WA) as reported by Jiao
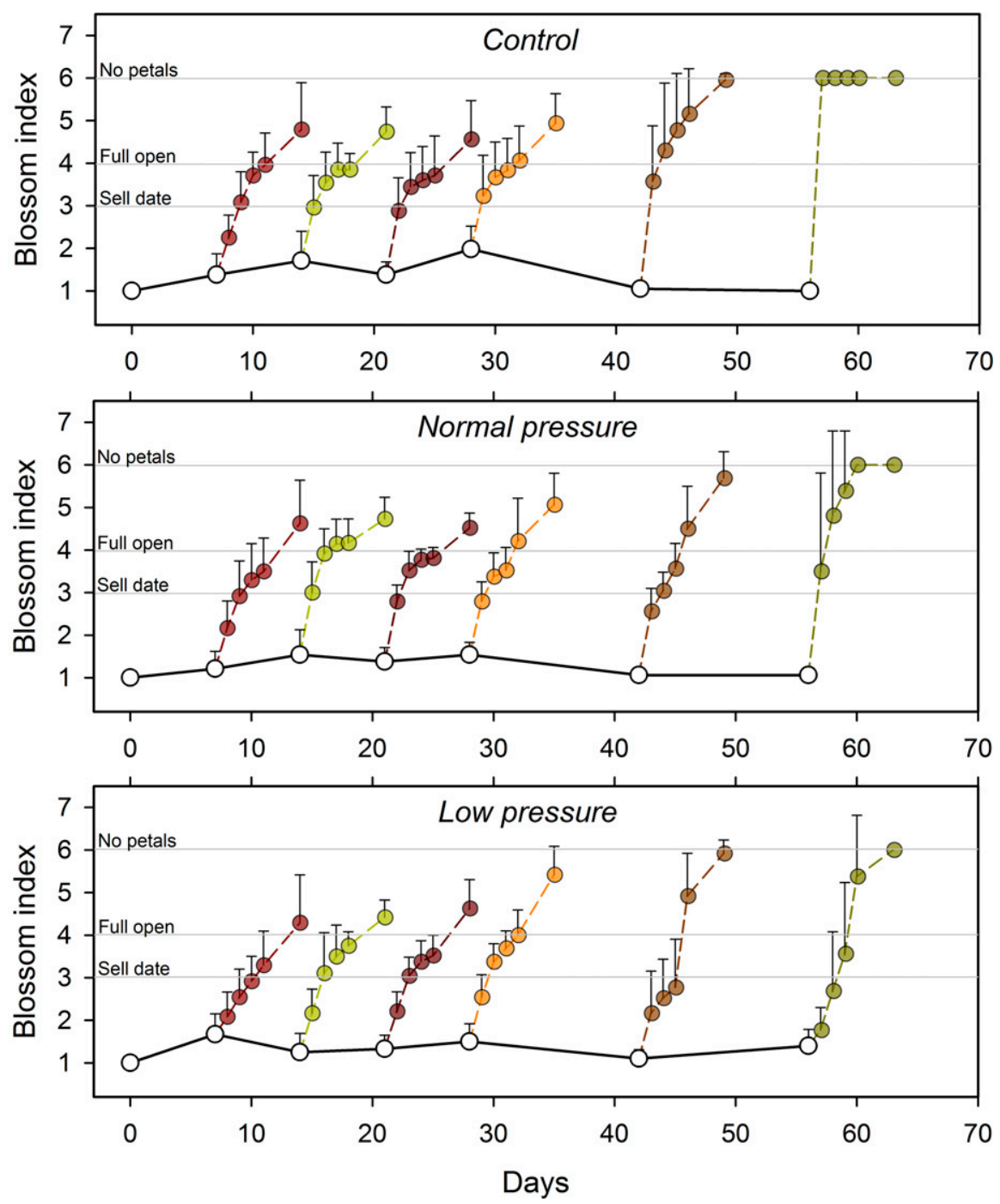

Fig. 6. Change in blossom quality index (1-6) of roses after $0,7,14,21,28,42$, and $56 \mathrm{~d}$ storage at $2{ }^{\circ} \mathrm{C}$ (open symbols) and for an additional $7 \mathrm{~d}$ following storage at $20^{\circ} \mathrm{C}$ (colored symbols). Storage was in humidified, 180 -L aluminum chambers operated at normal pressure $(101.3 \mathrm{kPa})$, low pressure $(1.9 \mathrm{kPa})$, or at normal pressure in commercial shipping cartons without humidity control (Control). Storage containers and shipping boxes were held in an environmental chamber maintained at $2{ }^{\circ} \mathrm{C}$ and an $\mathrm{RH}$ of $\approx 70 \%$. et al. (2012). Because our temperature control was similar, the slight difference was likely due to the presence of transpiring produce and absence of leakage in the chambers in the current study.

A much lower rate of weight loss than that reported here for these commodities would be expected if the chambers were filled to capacity ( $\approx 10 \mathrm{~kg}$ capacity) because the water loss would be distributed over a larger mass of product. Because the exiting atmosphere was essentially at saturation, a full chamber having 8 -fold more product (i.e., 10 $\mathrm{kg}$ ) would be expected to lose the same amount of water per minute if the flow rates were similar; however, as a proportion of total weight of product in the chamber, the water loss rate would be roughly one-eighth of that lost in this study (e.g., $0.03 \%$ per day). van den Berg and Lentz (1974) found similar low levels of moisture loss $(0.0 \%$ to $0.1 \%$ per day at 1 to $2{ }^{\circ} \mathrm{C}$ ) for leafy and bulky vegetables when stored at or near saturation for 30 d. In their study, the extreme high humidity did not increase losses due to decay or removal of senescent tissues. When surface condensation was induced, net weight gain occurred with no increase in losses.

Analysis of variance indicated operating pressure of the storage chambers did not affect weight loss $(P=0.496)$. This was taken to indicate that moisture loss was well controlled in LP as long as the humidity was maintained properly. This is in contrast to several reports for systems suffering from improper design (Hughes et al., 1981; Ilangantileke et al., 1989; Lougheed et al., 1977, 1978), but consistent with the assertions of Burg $(2004,2015)$ for more suitable LPS designs. There was no pressure $\times$ commodity interaction $(P=0.429)$, indicating absolute mass loss was not differentially affected by combinations of pressure and commodity. There was, however, a significant effect of commodity $(P<0.001$, Fig. 5). Strawberry fruit lost the least amount of moisture over 1 week of storage compared with the carrots or the spinach. This is likely because of the higher diffusive resistance of bulky tissues like fruit (Burg, 2004; Burg and Burg, 1965). Differences in sugar content might affect the potential of the commodities to retain water, but the sugar content of strawberry $(\approx 6 \%)$, carrot root $(\approx 5 \%)$, and spinach $(\approx 0.6 \%)$, would have only a marginal impact on $\psi_{\mathrm{S}}$ (Dilley et al., 1975; U.S. Deparment of Agriculture, 2019). Interestingly, relative to the total moisture lost for the combined products, the proportion lost by strawberry was higher $(P=0.002)$ at LP $(0.21 \%$ of the total $)$ than when stored at NP $(0.075 \%$ of the total $)$. This is likely because LP facilitates diffusion of gases even in the interior of bulky tissues (Burg, 2004, 2015), diminishing the impact of the diffusive resistance in the bulky tissue and making them behave more similarly to leafy or high surface area products. There were no apparent differences in wilting or leaf yellowing of the spinach between NP and LP storage, which, respectively, averaged 

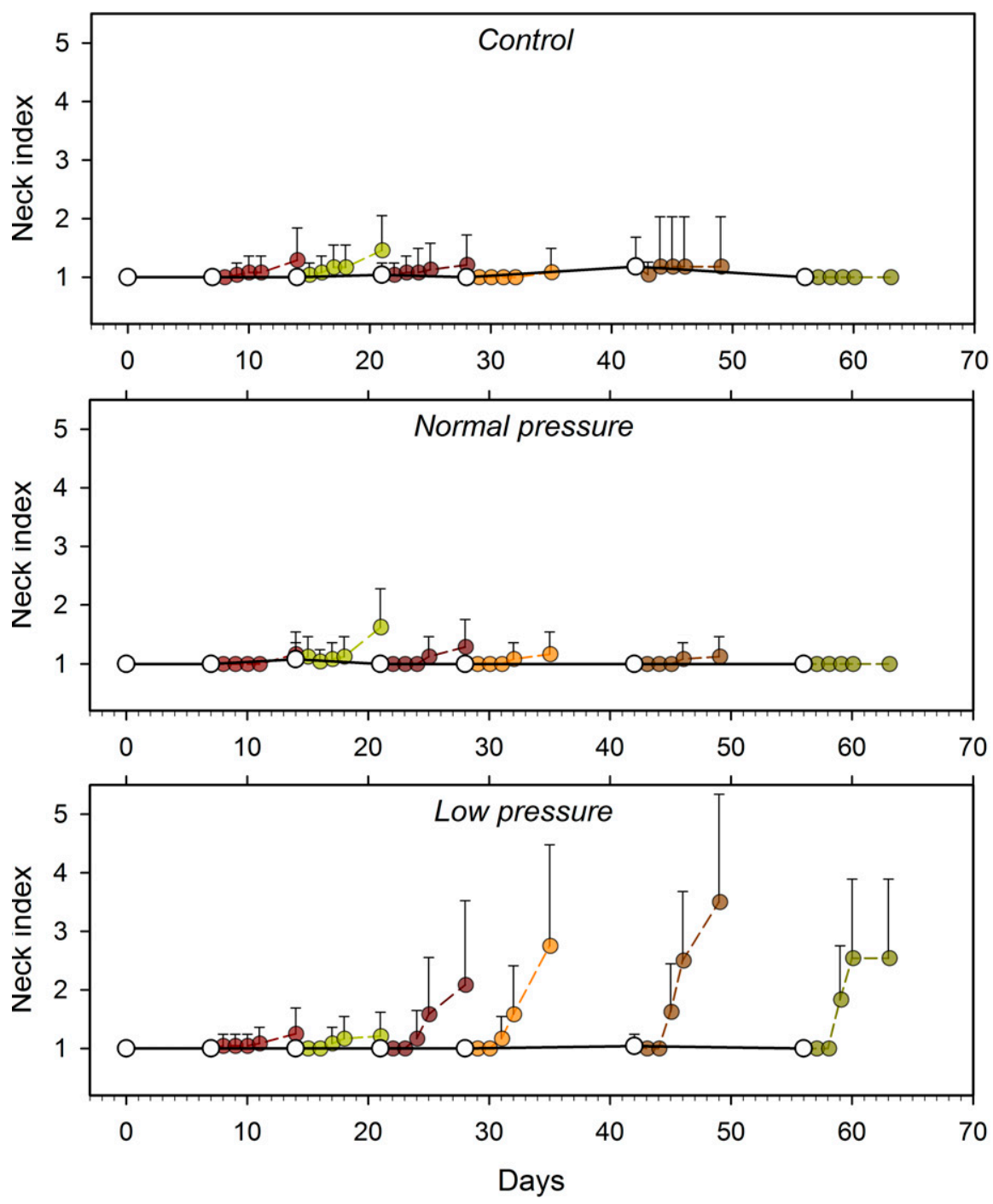

Fig. 7. Change in neck quality index (1-5) of roses after $0,7,14,21,28,42$, and $56 \mathrm{~d}$ storage at $2^{\circ} \mathrm{C}$ (open symbols) and for an additional $7 \mathrm{~d}$ following storage at $20^{\circ} \mathrm{C}$ at $70 \% \mathrm{RH}$ (colored symbols). Storage was in humidified, $180-\mathrm{L}$ aluminum chambers operated at normal pressure $(101.3 \mathrm{kPa})$ or low pressure $(1.9 \mathrm{kPa})$ or at normal pressure in commercial shipping cartons without humidity control (Control). Storage containers and shipping boxes were held in an environmental chamber maintained at $2{ }^{\circ} \mathrm{C}$ and a relative humidity of $\approx 70 \%$.

$22 \%$ and $7 \%$ of the product weight following 3 weeks of storage at $2{ }^{\circ} \mathrm{C}$ (data not shown).

The temperatures of objects in the chamber (dry bulb, wet bulb, crate, chamber wall, and perishable product) were within $0.21^{\circ} \mathrm{C}$ of one another (Table 2). The temperature of the products tended to be lower than the crate or air, suggesting evaporative cooling prevented temperature buildup from respiratory activity according to the Dewar effect (Dilley et al., 1975). There was some difference in the chamber temperatures, likely due to placement of the chambers and their proximity to the air stream from the evaporator coils in the controlled environment room. Wet bulb temperatures were consistently lower than the dry bulb temperatures, verifying the existence of evaporative activity in the chamber. However, the temperature difference averaged only $0.032^{\circ} \mathrm{C}$, which is characteristic of an $\mathrm{RH}$ of $\approx 99.76 \%$ at a temperature of $2{ }^{\circ} \mathrm{C}$.
The data clearly demonstrate adequate temperature and humidity control for extended storage of bulky and leafy vegetables can be achieved in LPS systems operated at low temperatures, although not all products respond positively to LPS environments. Additional improvement in humidity control may be achieved by additional heating of the humidification device, reducing ventilation rate, and maximizing chamber product loading. However, accurate measurement of humidity at levels above $99.9 \%$ may be challenging. Ventilation of the chamber using an airstream with an elevated $\mathrm{O}_{2}$ partial pressure would permit a reduction in the rate of ventilation and should bring about a reduction in the rate of water loss, although this has not been tested to our knowledge.

Expt. 2. The rate of weight loss by the sleeves of roses was $\approx 0.21 \%, 0.12 \%$, and $0.071 \%$ per day, respectively, for NP storage in commercial rose boxes, NP storage in the 180 -L chamber, and LP storage in the $180-\mathrm{L}$ chamber when averaged over the latter half of the study (Table 3 ). These data are similar to those throughout the duration of the study (data not shown). As anticipated, the rate of moisture loss in the LP chamber in Expt. 2 was considerably less than that of the combined products in Expt. 1. Based on the rate of moisture loss in Expt. 1, the $5.1 \mathrm{~kg}$ of roses would be expected to lose $\approx 0.06 \%$ of their weight per day, which is similar to the measured rate of $0.071 \%$ per day. Differences in gas resistances and the repeated opening of the chamber may have contributed to the slightly higher than expected moisture loss. Further, while the use of protective sleeves may have also provided some benefit in terms of slowing water loss, the improved diffusion at LP would likely have minimized this effect. The total water "loss" per chamber was calculated to be $\approx 270 \mathrm{~g}$ based on ventilation rate and the humidity of the exiting air, which was effectively at saturation. The three replicate runs in this experiment, each containing $5.1-\mathrm{kg}$ samples of roses, lost an average of $146 \pm 28 \mathrm{~g}$ of water after 8 weeks of storage, suggesting that $\approx 46 \%$ of the water exiting the chamber was derived from the humidification flask.

Corolla quality index for roses held in storage in NP or in LP remained very stable at $\approx 1.5$ throughout the storage period (Fig. 6 ); however, on removal from storage and placement into the retail simulation chamber at $20^{\circ} \mathrm{C}$, the stage of development changed rapidly (Fig. 6). No bluing of the corollas was detected (Supplemental Figs. 1-6). The time to reach a stage 3 , considered the limit of marketability (i.e., end of shelf life), differed slightly for the storage treatments. Generally, the LP treatment tended to open more slowly than the NP treatments, consistent with previous findings (Staby et al., 1984). This was especially noticeable by week 6 . By week 8 , the NP shipping box treatment clearly yielded the poorest quality, as all of the corollas fell from the stems within 1 day of removal from storage. Petal loss was associated with decay, which was most pronounced for the roses stored in the NP shipping box after 6 weeks of storage (Supplemental Figs. 7 and 8 ).

"Bent neck," caused by wilting of the flower, was essentially absent on removal of the roses from NP and LP storage, even after 8 weeks (Fig. 7, Supplemental Figs. 1-6); however, in the shelf life environment, only the LP storage regimen flowers sustained a meaningful level of bending of the flower neck. Staby et al. (1984) commented that LP storage yielded a slight improvement in poststorage shelf life, but other quality issues and large cultivar-to-cultivar variability suggested LPS offered little benefit to rose. They did not mention bent neck, but noted that recutting the stems underwater poststorage was helpful in improving appearance during shelf life evaluations and noted that LP-stored roses did not benefit from this treatment. In the current study, loss of hydration of the stem 
region subtending the flower was pronounced, leading to the propensity for bent neck in LPstored flowers. Given that the moisture loss was less for the LP-stored roses than for the NP roses, the cause for the differing shelf life behavior is likely related to the distribution or location of the water loss, rather than its absolute amount. The greater diffusion of gases enabled by the LP environment might have enhanced the loss of water from interior tissues, perhaps to the point of causing embolisms distant from the cut base, leading to an impairment of vascular connectivity.

Despite the lower rate of moisture loss in the LP treatment, the quality of the roses was no better than the NP chamber treatment for the 8 weeks of the study. During the latter half of the storage (4 weeks and later), losses due to yellowing of the petals was highest for the roses held in the commercial shipping boxes, but similar for the NP and LP chambers (Table 3 ). The proportion of flowers with completely decayed corollas did not differ between treatments over the latter half of the storage (Table 3). However, the percentage of roses with at least some level of decay visibly differed on week 8 for the flowers stored in the commercial shipping boxes (Supplemental Fig. 8). LPS is reported to suppress decay development on a number of commodities, including roses (Burg, 2015). Leaves of roses stored under LP suffered some damage, as evidenced by small lesions scattered across the leaf surface in no apparent pattern (Supplemental Fig. 9). This LP disorder is consistent with previous findings on LPS of rose flowers (Staby et al., 1984).

The data demonstrated that in a well-designed, laboratory-scale LPS system, RH can be maintained at levels exceeding $99.5 \%$ with no appreciable difference in water loss compared with properly managed, refrigerated air storage at high humidity. Despite the excellent performance at restricting moisture loss (less than 3\% moisture loss in 8 weeks), LP storage sensitized rose stems to the development of bent neck. Consequently, LP does not appear to offer meaningful benefit to roses compared with those held at high humidity at NP, in contrast to the assertion of Burg (2004) and it is difficult to imagine the potential for recouping the considerable costs associated with deploying this technology for this commodity. It is likely its most beneficial application will be for commodities for which reductions in ethylene action improve storability and for those commodities for which decay suppression is critical in improving storability.

\section{Literature Cited}

Beaudry, R.M. 1999. Effect of $\mathrm{O}_{2}$ and $\mathrm{CO}_{2}$ partial pressure on selected phenomena affecting fruit and vegetable quality. Postharvest Biol. Technol. 15:293-303, doi: 10.1016/S0925-5214(98) 00092-1.

Beaudry, R.M. 2000. Responses of horticultural commodities to low oxygen: Limits to the expanded use of modified atmosphere packaging. HortTechnology 10:491-500, doi: 10.21273/ HORTTECH.10.3.491.

Burg, S.P. 2004. Postharvest physiology and hypobaric storage of fresh produce. CAB International, Wallingford, U.K.

Burg, S.P. 2015. Hypobaric storage in food industry: Advances in application and theory. Academic Press, Elsevier, Amsterdam, The Netherlands, doi: 10.1016/C2013-0-09887-8.

Burg, S.P. and E.A. Burg. 1965. Gas exchange in fruits. Physiol. Plant. 18:870-884, doi: 10.1111/ j.1399-3054.1965.tb06946.x.

Capdeville, G.D., L.A. Maffia, F.L. Finger, and G.B. Ulisses. 2005. Pre-harvest calcium sulfate applications affects vase life and severity of gray mold in cut roses. Scientia Hort. 103:329-338, doi: 10.1016/j.scienta.2004.06.016.

Day, B.P.F. 2001. Modified atmosphere packaging of fresh fruit and vegetables - an overview. Acta Hort. 553:585-590, doi: 10.17660/ActaHortic. 2001.553.138

Dilley, D.R., W.J. Carpenter, and S.P. Burg. 1975. Principles and application of hypobaric storage of cut flowers. Acta Hort. 41:249-267, doi: 10.17660/ActaHortic. 1975.41.21.

Hardenburg, R.E., A.E. Watada, and C.Y. Wang. 1986. The commercial storage of fruits, vegetables, and florist and nursery stocks. U.S. Dept. Agr., Agr. Handbook 66 (revised).

Hughes, P.A., A.K. Thompson, R.A. Plumbley, and G.B. Seymour. 1981. Storage of Capsicums (Capsicum-annuum (L.) Sendt.) under controlled atmosphere, modified atmosphere and hypobaric conditions. J. Hort. Sci. 56:261-266, doi: 10.1080/00221589.1981.11514999.

Ilangantileke, S.O., L.O. Turla, and R.C. Chen 1989. Pretreatment and hypobaric storage for increased storage life of mangos. Amer. Soc. Agr. Sci., St. Joseph, MI. 15 pps.

Jiao, S., J.A. Johnson, J.K. Fellman, D.S. Mattinson, J. Tang, T.L. Davenport, and S. Wang. 2012. Evaluating the storage environment in hypobaric chambers used for disinfesting fresh fruits. Biosyst. Eng. 111:271-279, doi: 10.1016/j.biosystem seng.2011.12.003.

Koger, C. 2021. RipeLocker containers designed to extend produce shelf life. The Packer, 14 Jan. 2021. < https://www.thepacker.com/news/ packer-tech/ripelocker-containers-designedextend-produce-shelf-life $>$.
Lougheed, E.C., D.P. Murr, and L.E. Berard. 1977. LPS-great expectations. Proc. 2nd Intl. Controlled Atmosphere Res. Conf., 5-7 Apr. 1977, Mich. State Univ. p. 38-44.

Lougheed, E.C., D.P. Murr, and L. Berard. 1978. Low-pressure storage for horticultural crops. HortScience 13:21-27.

Mastromatteo, M., A. Conte, and M.A. Del Nobile. 2012. Packaging strategies to prolong the shelf life of fresh carrots (Daucus carota L.). Innov. Food Sci. Emerg. Technol. 13:215-220.

Mudau, A.R., P. Soundy, H.T. Araya, and F.N. Mudau. 2018. Influence of modified atmosphere packaging on postharvest quality of baby spinach (Spinacia oleracea L.) leaves. HortScience 53:224-230, doi: 10.21273/HORTSCI12589-17.

Nunes, M.C.N., J.K. Brecht, A.M.M.B. Morais, and S.A. Sargent. 1998. Controlling temperature and water loss to maintain ascorbic acid levels in strawberries during postharvest handling. J. Food Sci. 63:1033-1036, doi: 10.1111/j.1365-2621. 1998.tb15848.x.

The New York Times. 1982. Grumman closing its Dormavac unit. New York Times, 16 Apr. 1982. 24 Feb. 2021. <https://www.nytimes.com/1982/ 04/16/business/grumman-closing-its-dormovacunit.html $>$.

Patterson, B.D., C. Flodin, and J.H. Bower. 1999. The oxygen level in relation to oxygen supply and demand within modified atmosphere packages containing fresh plant produce. 20th Intl. Congr. Refrigeration, IIR/IIF, Sidney, 1999. Vol. IV, paper 149.

Staby, G.L., M.S. Cunningham, C.L. Holstead, J.W Kelly, P.S. Konjoian, B.A. Eisenberg, and B.S. Dressler. 1984. Storage of rose and carnation flower. J. Amer. Soc. Hort. Sci. 109:193-197.

Tomkins, R.G. 1962. Film packaging of fresh fruit and vegetables - the influence of permeability, p. 64-69. In: Inst. Packaging Conf. Guide 1961, Larkfield, Maidstone, Kent, England.

U.S. Deparment of Agriculture. 2019. FoodData Central. USDA-ARS. 23 Feb. 2021. <https:// fdc.nal.usda.gov/fdc-app.html\#/food-details/ $357642 /$ nutrients $>$.

Vaisala, O. 2013. Humidity conversion formulas: Calculation formulas for humidity. Publication No. B210973EN-F, Vaisala Oyj, Helsinki, Finland, 17 pp., 23 Feb. 2021. <https://www. hatchability.com/Vaisala.pdf $>$.

van den Berg, L. and C.P. Lentz. 1974. High humidity storage of some vegetables. Canadian Inst. Food Sci. Tech. J. 7:260-262, doi: 10.1016/S0315-5463(74)73924-4.

Wagner, W. and A. Pruß. 2002. The IAPWS formulation 1995 for the thermodynamic properties of ordinary water substance for general and scientific use. J. Phys. Chem. Ref. Data 31:387-535, doi: $10.1063 / 1.1461829$.

Zheng, H. 2018. Research and application of hypobaric storage technology in agriculture and food industry in China. Asian Agr. Res. 10:40-51, doi: 10.19601/j.cnki.isn1943-903.2018.6.09. 

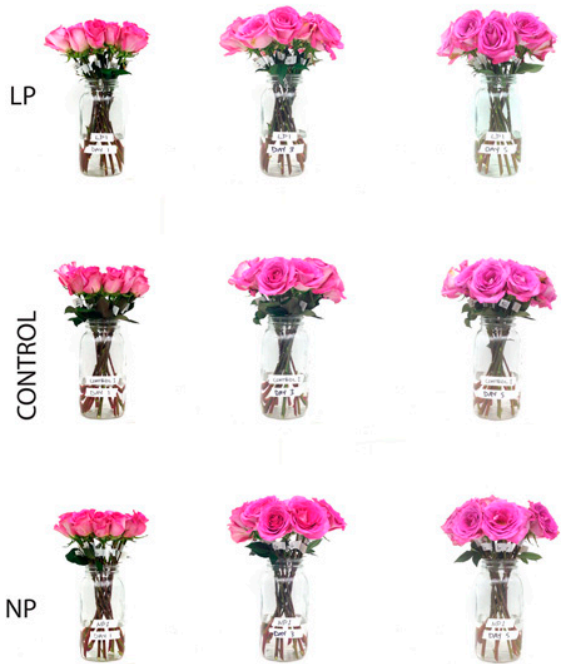

DAY 1

DAY 3
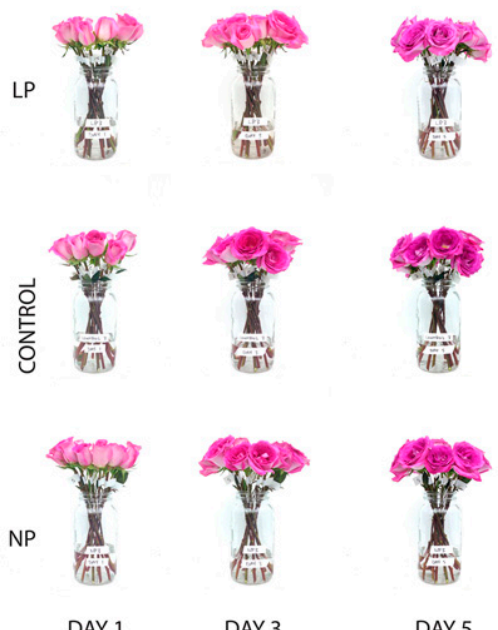

Supplemental Fig. 3. Appearance of roses after holding them for 1,3 , and $5 \mathrm{~d}$ at $20^{\circ} \mathrm{C}$ and $70 \%$ relative humidity following 3 weeks' storage in $180-\mathrm{L}$ chambers operated at normal pressure $(\mathrm{NP}, 101.3 \mathrm{kPa})$ or low pressure (LP $1.9 \mathrm{kPa}$ ) or stored in commercial shipping cartons at NP (Control) at $2^{\circ} \mathrm{C}$. storage in $180-\mathrm{L}$ chambers operated at normal pressure (NP, $101.3 \mathrm{kPa}$ ) or low pressure (LP, $1.9 \mathrm{kPa})$ or stored in commercial shipping cartons at NP (Control) at $2^{\circ} \mathrm{C}$.

upplemental Fig. 1. Appearance of roses after holding them for 1,3 , and $5 \mathrm{~d}$ at $20^{\circ} \mathrm{C}$ and

WEEK 2
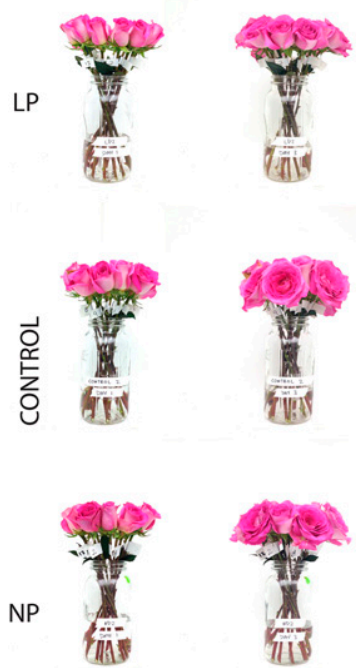

DAY 1
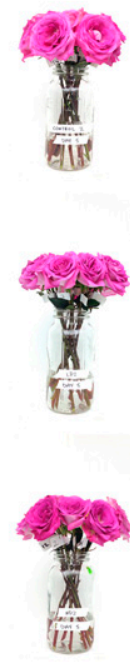

DAY 5

Supplemental Fig. 2. Appearance of roses after holding them for 1,3 , and $5 \mathrm{~d}$ at $20^{\circ} \mathrm{C}$ and $70 \%$ relative humidity following 2 weeks' storage in $180-\mathrm{L}$ chambers operated at normal pressure $(\mathrm{NP}, 101.3 \mathrm{kPa}$ ) or low pressure (LP, $1.9 \mathrm{kPa}$ ) or stored in commercial shipping cartons at NP (Control) at $2{ }^{\circ} \mathrm{C}$.
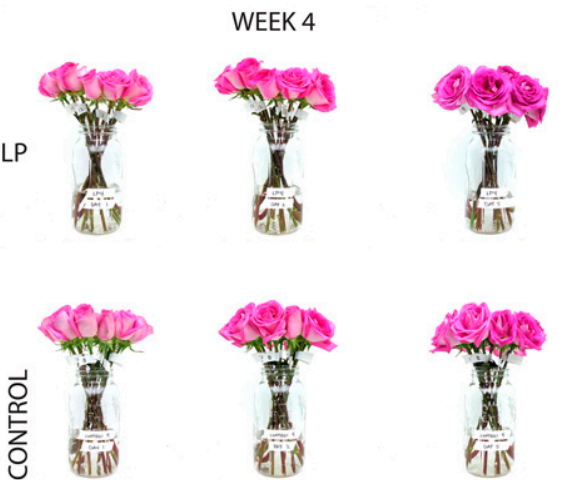

NP
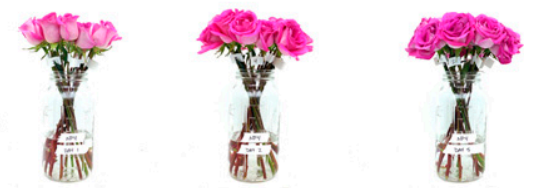

DAY 1
LP
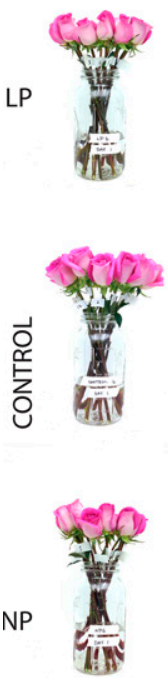

DAY 1
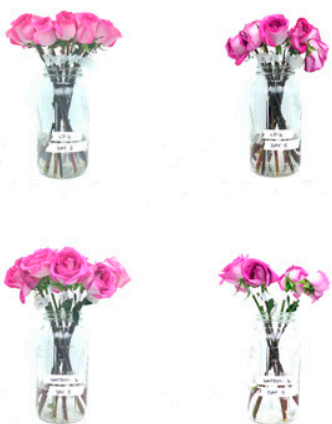

Supplemental Fig. 5. Appearance of roses after holding them for 1,3 , and $5 \mathrm{~d}$ at $20^{\circ} \mathrm{C}$ and $70 \%$ relative humidity following 6 weeks storage in 180-L chambers operated at normal pressure (NP, $101.3 \mathrm{kPa}$ ) or low pressure (LP, $1.9 \mathrm{kPa}$ ) or stored in commercial shipping cartons at $\mathrm{NP}$ (Control) at $2^{\circ} \mathrm{C}$.
Supplemental Fig. 4. Appearance of roses after holding them for 1,3 , and $5 \mathrm{~d}$ at $20^{\circ} \mathrm{C}$ and $70 \%$ relative humidity following 4 weeks' storage in 180 -L chambers operated at normal pressure $(\mathrm{NP}, 101.3 \mathrm{kPa}$ ) or low pressure (LP, $1.9 \mathrm{kPa}$ ) or stored in commercial shipping cartons at NP (Control) at $2^{\circ} \mathrm{C}$.
LP

WEEK 8
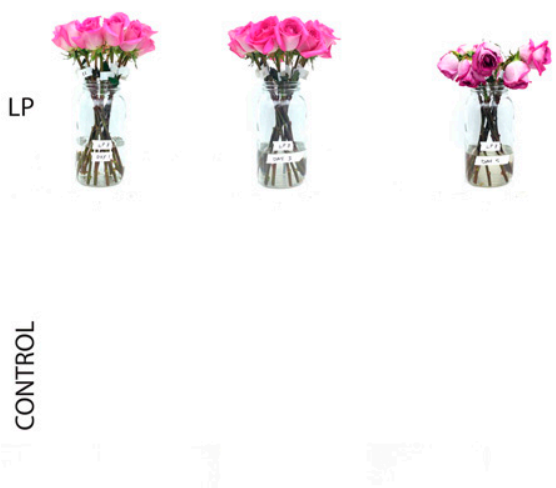

NP
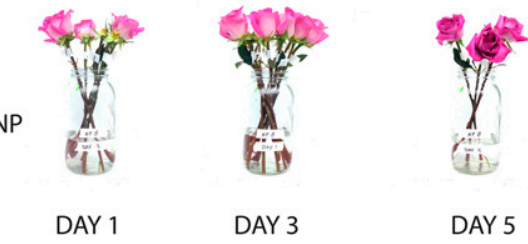

DAY 5

Supplemental Fig. 6. Appearance of roses after holding them for 1,3 , and $5 \mathrm{~d}$ at $20^{\circ} \mathrm{C}$ and $70 \%$ relative humidity following 8 weeks' storage in $180-\mathrm{L}$ chambers operated at normal pressure (NP, $101.3 \mathrm{kPa}$ ) or low pressure (LP, $1.9 \mathrm{kPa})$ or stored in commercial shipping cartons at NP (Control) at $2^{\circ} \mathrm{C}$. Control roses had dropped all petals within a day of removal from cold storage and are not depicted. 

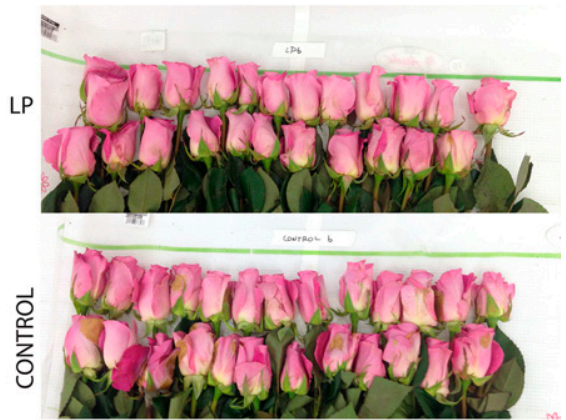

titi

NP

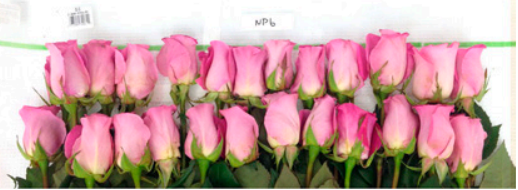

Supplemental Fig. 7. Appearance of roses after immediately after storage for 6 weeks in 180-L chambers operated at normal pressure (NP, $101.3 \mathrm{kPa}$ ) or low pressure (LP, $1.9 \mathrm{kPa}$ ) or stored in commercial shipping cartons at NP (Control) maintained at $2^{\circ} \mathrm{C}$. Decay of petals and sepals is suspected to be due to Botrytis sp.
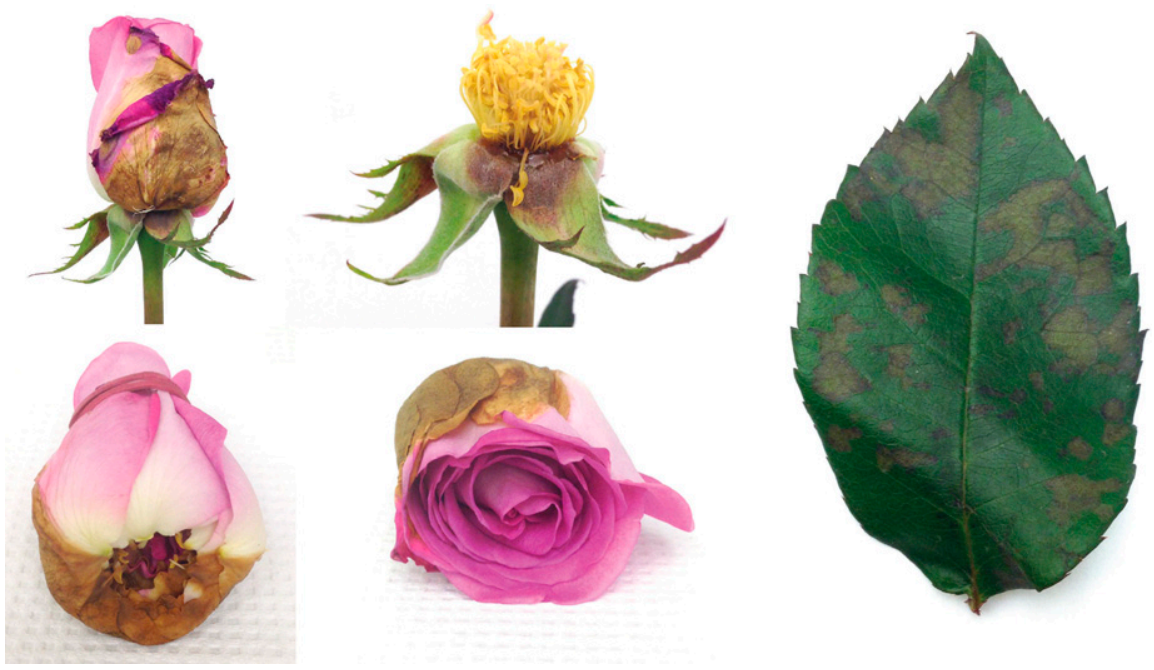

Supplemental Fig. 9. Appearance of rose flower, sepal, and leaf tissue following storage for 6 to 8 weeks in high humidity chambers maintained at $2^{\circ} \mathrm{C}$ at normal pressure $(\mathrm{NP} ; 101 \mathrm{kPa})$, or low pressure $(\mathrm{LP} ; 1.9 \mathrm{kPa})$, or in commercial shipping boxes. Decay and petal loss was found in all treatments after 6 weeks' storage, but was much more extensive in roses stored at NP in shipping boxes. Lesions on leaf were found only on roses stored at LP.
WEEK 8
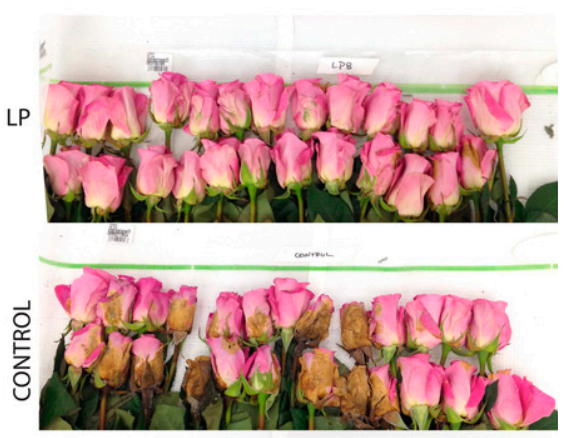

NP

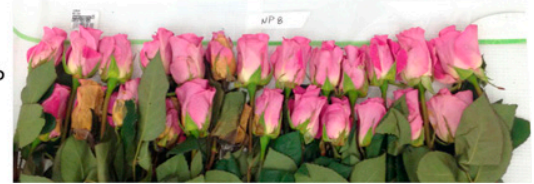

Supplemental Fig. 8. Appearance of roses immediately after storage for 8 weeks in 180 -L chambers operated at normal pressure (NP, 101.3 $\mathrm{kPa})$ or low pressure $(\mathrm{LP}, 1.9 \mathrm{kPa})$ or stored in commercial shipping cartons at NP (Control) maintained at $2^{\circ} \mathrm{C}$. Decay of petals and sepals is suspected to be due to Botrytis sp. 